\title{
Depression accelerates the development of gastric cancer through reactive oxygen species-activated ABL1 (Review)
}

\author{
TIANHE HUANG ${ }^{1}$, FULING ZHOU ${ }^{2}$, FENG WANG-JOHANNING ${ }^{3}$, KEJUN NAN $^{1}$ and YONGCHANG WEI ${ }^{1,4}$ \\ ${ }^{1}$ Department of Oncology, The First Affiliated Hospital of Xi'an Jiaotong University, Xi'an, Shaanxi 710061; \\ ${ }^{2}$ Department of Clinical Hematology, Zhongnan Hospital, Wuhan University, Wuhan, Hubei 430071, P.R. China; \\ ${ }^{3}$ Viral Oncology Program, SRI International, Menlo Park, CA 94025, USA; ${ }^{4}$ Department of Radiation \\ and Medical Oncology, Zhongnan Hospital, Wuhan University, Wuhan, Hubei 430071, P.R. China
}

Received May 10, 2016; Accepted September 5, 2016

DOI: $10.3892 /$ or.2016.5127

\begin{abstract}
Depression is a common symptom among gastric cancer (GC) patients and serves as a potential indication of poor prognosis and advanced cancer clinical stage. However, the molecular mechanism of depression-associated poor prognoses of GC patients remains unclear. Recent studies have revealed that GC patients with depression are under high levels of oxidative stress (OS) status that is accompanied by the dysfunction of numerous proto-oncogenes, including the ABL proto-oncogene 1 (ABL1), which is a non-receptor tyrosine kinase. Recent evidence indicates that ABL1 was dysregulated in both major depressive disorder (MDD) and cancer patients with depression, and high levels of reactive oxygen species (ROS) can lead to the activation of ABL1 in response to OS and that activated ABL1 subsequently contributes to development of GC via interactions with the downstream targets and corresponding signaling pathways. In this review, we examine the evidence to illuminate the molecular mechanism of ABL1 in the progression of GC patients with depression and identify out new and effective methods for the initial and long-term treatment of GC.
\end{abstract}

\section{Contents}

1. Introduction

2. Elevated levels of ROS are generated in GC patients with depression

3. ROS generated in GC lead to the activation of ABL1

4. ABL1 contributes to cancer development in GC patients with depression

Correspondence to: Professor Yongchang Wei, Department of Radiation and Medical Oncology, Zhongnan Hospital, Wuhan University, No. 169 East Lake Road, Wuhan, Hubei 430071, P.R. China

E-mail: weiyongchang8@163.com

Key words: depression, gastric cancer, cancer development, reactive oxygen species, ABL proto-oncogene 1
5. Conclusions

6. Perspective

\section{Introduction}

Despite the decline in the morbidity of gastric cancer (GC) in recent years, $\mathrm{GC}$ remains the fourth most common cancer and the second-leading cause of cancer-related death globally with $>700,000$ human deaths per year $(1,2)$. The occurrence of depression challenges cancer treatment and acts as an underlying indicator of advanced stages and poor prognoses of cancer patients (3). Depression care for cancer patients can improve the clinical benefit, including the treatment response $(4,5)$. Nevertheless, there are currently no clear theories to explain the molecular mechanism by which depression is associated with poor prognoses among cancer patients. As an insult to the human body, depression causes oxidative stress (OS) (6), which subsequently leads to the excessive generation of reactive oxygen species (ROS) (7). Gastric tissues are particularly vulnerable to ROS (8). Excessive ROS that exceed the scavenging ability of human body trigger carcinogenesis by activating diverse proto-oncogenes, including ABL proto-oncogene 1 (ABL1) $(9,10)$.

ABL1 is a non-receptor tyrosine kinase that consists of the N-terminal Src homology 3 (SH3) domain, Src homology 2 (SH2) domain, kinase domains, and the C-terminal actin-binding domain (ABD) (11). ABL1 was upregulated in $\mathrm{GC}$ and colorectal cancer patients with depression, and patients with major depressive disorder (MDD) $(12,13)$. Activated ABL1 can regulate nuclear factor (erythroid-derived 2)-like 2 (NRF2) to function in an adaptive manner to react to OS (14). Additionally, activated ABL1 can consequently lead to dysfunctions of its downstream targets and corresponding signaling pathways, e.g., the mitogen-activated protein kinase (MAPK) and mechanistic target of rapamycin (mTOR), which contributes to the promotion of the development of GC and results in poor prognosis (14-17). Therefore, we will collect the evidence that ROS-activated ABL1 is responsible for the poor prognoses of GC patients with depression. Because inhibitors of ABL1, such as vandetanib, are widely used in clinical tumor treatment, clearly understanding the ABL1 in the process of 
GC will provide new methods to improve the prognoses of GC patients with depression.

\section{Elevated levels of ROS are generated in GC patients with depression}

Depression symptoms are common among GC patients both in Asia and the West (2,18-20). According to published reports, the prevalence of depression is $\sim 50 \%$ among GC patients $(2,21,22)$. The interaction of depression with cancer has long been a subject of investigation. The unambiguous mechanism responsible for the occurrence of depression among GC patients remains unknown. Inflammation is a crucial factor in gastric carcinogenesis (23). Due to inflammation, leukocytes release increased levels of cytokines and chemokines, e.g., TNF- $\alpha$, IL- 6 , and chemokine (C-X-C motif) ligand 12 (CXCL12) (24-26). These cytokines and chemokines interact with the hypothalamic-pituitary-adrenal (HPA) axis, which may explain some of the mechanism of depression (27). Additionally, cancer diagnosis, post-diagnosis treatment, and cancer-related fatigue may also account for the occurrence of depression in GC (28). However, it is certain that depression is an indicator of poor prognosis among cancer patients, including patients with GC $(4,29)$. In addition to other authors, we have suggested that depression is common among $\mathrm{GC}$ patients in our previous study (21). Compared with patients without depression, GC patients with depression exhibit shorter survival times. Furthermore, the prevalence of depression is positively correlated with the clinical stage of GC, i.e., GC patients with depression are susceptible to advanced stage cancer (22).

Emerging evidence suggests that OS works as primary crosslink between depression and GC. OS is primarily caused by the imbalance between oxidation and antioxidation in vivo. The recognized marker of OS 8-hydroxydeoxyguanosine (8-OHdG) is positively correlated with Hospital Anxiety and Depression Scale (HADS)-D scores (30). Under OS, ROS levels are particularly raised among patients with depression. Decreased antioxidants and elevated oxidants enhance the generation of ROS in patients with depression. Clinical studies have revealed that depressive patients exhibit decreased levels of antioxidants, including glutathione peroxidase (GPX), catalase and superoxide dismutase (SOD), and these antioxidants exhibit ROS scavenging activities (31-33). Patients with depression also exhibit elevated levels of oxidants, such as nicotinamide adenine dinucleotide phosphate (NADPH) oxidase and xanthine oxidase (XO), which leads to the production of ROS (34-37). Indeed, antidepressant treatment has been reported to reduce MDA (6). Our team discovered that 8-OHdG is significantly elevated in the sera of cancer patients, including GC patients, with depression compared with those without depression $(13,21)$. All of the above changes could lead to the excessive generation of ROS (Fig. 1).

\section{ROS generated in GC lead to the activation of ABL1}

ABL1 is well known for its characteristics related to chronic myelogenous leukemia (CML) in the form of BCR-ABL1, which mediates abnormal myeloproliferation and leads to the development of CML (38). As a non-receptor tyrosine kinase, ABL1 is expressed in the cytoplasm and the nucleus and is involved

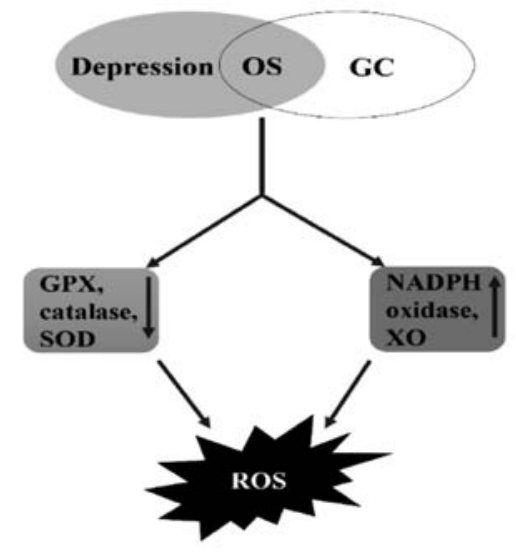

Figure 1. High levels of ROS in GC patients with depression. Decreased levels of antioxidants, including GPX, catalase and SOD, cooperate with increased levels of oxidants, including NADPH oxidase and $\mathrm{XO}$, to promote the generation of ROS in GC patients with depression. ROS, reactive oxygen species; GC, gastric cancer; GPX, glutathione peroxidase; SOD, superoxide dismutase; NADPH, nicotinamide adenine dinucleotide phosphate; $\mathrm{XO}$, xanthine oxidase.

in the processes of cell differentiation, proliferation, adhesion, and stress responses (39). Similar to other protein kinases, ABL1 is activated by a ligand and functions through interactions with downstream targets. Vitally, the expression of ABL1 is context-dependent and is upregulated in response to OS and DNA damage $(10,14,40)$. In diverse cancers with OS that are accompanied by DNA damage, including CML, acute lymphoblastic leukemia (ALL), kidney, breast, ovarian and colorectal cancers, as well as GC, ABL1 is highly expressed $(14,38,41-45)$. Thus, this system is a perfect model to probe the activation and the activities of ABL1 in fumarate hydratase-deficient kidney cancer. Fumarate hydratase deficiency results in the accumulation of fumarate, which subsequently leads to elevated NADPH oxidase levels and enhanced generation of ROS $(10,14)$. ROS levels are positively associated with the expression of ABL1. Hydrogen peroxide, a type of ROS, promotes ABL1 expression, and the ROS scavenger $N$-acetylcysteine (NAC) could inhibit ABL1 expression. Therefore, the metabolic maladjustment-associated accumulation of ROS is the primary cause of the activation of ABL1. Indeed, in some types of cancer, ABL1 has been found to be associated with the level of ROS. ABL1 expression in these cancers is ROS-dependent. OS and excessive ROS generation are well-documented contributors to carcinogenesis in GC $(33,46)$. In GC, ABL1 and c-Src tyrosine kinase (CSK) kinases phosphorylate cytotoxin-associated gene A ( $\mathrm{CagA})$, which is vital in the initial and development of gastric carcinogenesis (47). The activity of ABL1 is enhanced in the GTL-16 cell line (48). Therefore, the ROS generated in GC development might lead to the activation of ABL1. ROS can regulate the expression of ABL1; however, the potential mechanism is unknown.

The regulation of gene expression is a complex process, and only one report has discussed expression of ABL1 in $\mathrm{GC}$ as a target of miR-203. Epigenetically silenced miR-203 releases the expression of ABL1 to promote gastric lymphomagenesis (45). Furthermore, the increased expression of ABL1 by epigenetically silenced miR-203 has also been confirmed in CML $(49,50)$. In Helicobacter pylori (Hp)-induced GC, 


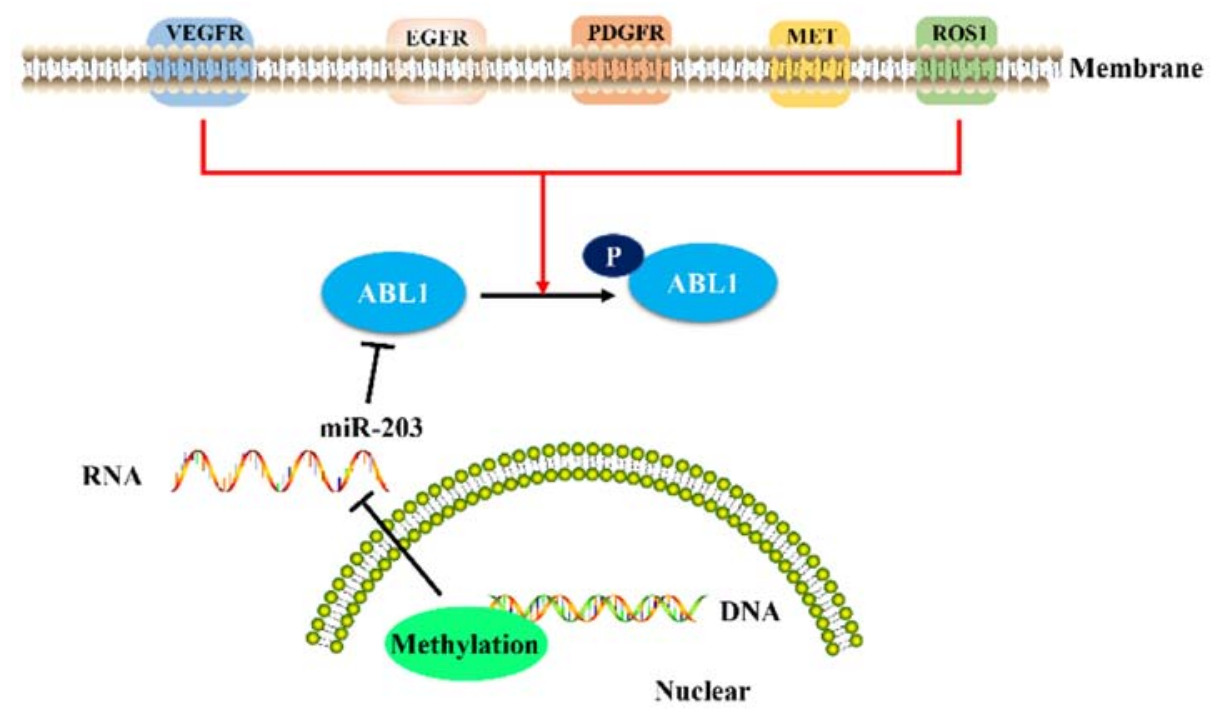

Figure 2. Expression and activation of ABL1 in GC. miR-203 and methylation can regulate the expression of ABL1 at the gene level. RTKs, including EGFR, PDGFR, VEGFR, MET, and ROS1 can activate ABL1. ABL1, ABL proto-oncogene 1; GC, gastric cancer; RTKs, receptor tyrosine kinases; EGFR, epidermal growth factor receptor; PDGFR, platelet-derived growth factor receptor; VEGFR, vascular endothelial growth factor receptor.

miR-203 has been confirmed to be downregulated. Therefore, miR-203 may be a reason for the high level of ABL1 in GC. As mentioned above, the expression of ABL1 is ROS-dependent, and ROS can influence methylation status by sustaining the stability of hypoxia-inducible factor $1 \alpha(\mathrm{HIF}-1 \alpha)(51)$, which increases the expression of the DNMT enzymes DNMT1 and DNMT3B, which keep gene silenced by hyper-methylation (52). Interestingly, HIF-1 $\alpha$ can also result in the hypo-methylation of genes by regulating the MAT1A/MAT2A switch (53). Given the role of ROS in the epigenetic regulation of gene expression, the expression of ABL1 may be mediated by the ROS-related hyper-methylation of miR-203. Moreover, although the methylation of ABL1 in GC has not been clarified, in CML, dynamic methylation changes in the ABL1 promoter have been clearly identified $(54,55)$. ROS might supervise the expression of ABL1 by directly influencing the methylation status of ABL1. Additionally, the activity of ABL1 can be triggered by receptor tyrosine kinases (RTKs), including epidermal growth factor receptor (EGFR), platelet-derived growth factor receptor (PDGFR), erb-b2 receptor tyrosine kinase 2 (ERBB2), vascular endothelial growth factor receptor (VEGFR), MET, c-ros oncogene 1, and receptor tyrosine kinase (ROS1), and their substrates $(9,19,20)$. Importantly, EGFR, PDGFR, VEGFR, MET, and ROS1 have been proven to be elevated in GC (56-60). Moreover, some RTKs, such as EGFR, are regulated by ROS, and MET has been confirmed to interact with ABL1 $(48,61)$. Therefore, ROS may affect the expression of ABL1 through a combination of a variety of mechanisms (Fig. 2). Additional studies should be designed to identify the detailed mechanism of the regulation of the expression of ABL1 by ROS in GC.

\section{ABL1 contributes to cancer development in GC patients with depression}

The function of ABL1 most strongly depends on its biological structure. As a tyrosine kinase, the $\mathrm{N}$-terminal $\mathrm{SH} 2$ regulates

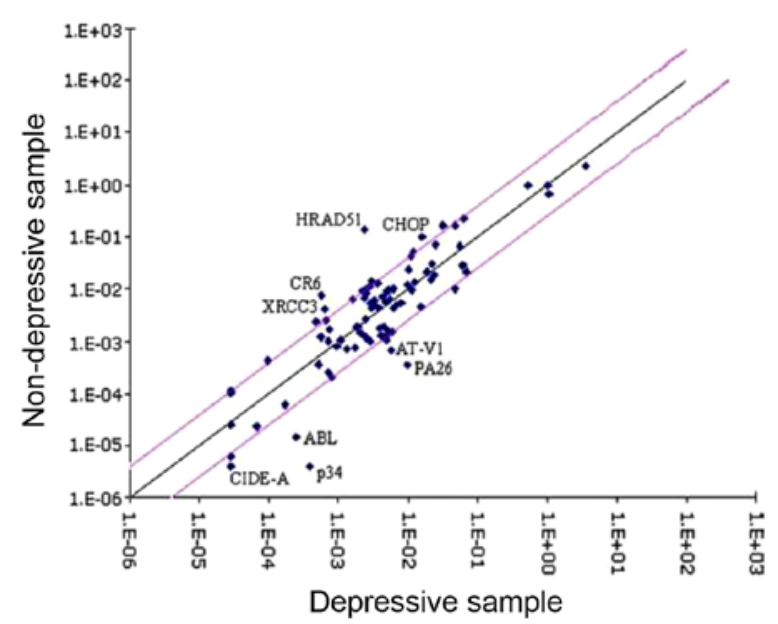

Figure 3. ABL1 was significantly increased in colorectal carcinoma patients with depression. ABL1, ABL proto-oncogene 1.

the activation of kinase domains via contact with the $\mathrm{SH} 2 / \mathrm{N}$-lobe interface $(62,63)$. The N-terminal SH3 is regulated by Ras and Rab interactor 1 (RIN1) and also influences the activation of ABL1 (64), and the kinase domain is involved its major activities. Based on its structure, ABL1 activates its substrates and associated signaling pathway to promote gastric tumorigenesis.

Both the expression and the activity of ABL1 are increased in GC $(48,65)$. Our preliminary study confirmed that genes involved in DNA-damage signaling pathways were markedly dysregulation by gene chips in GC and colorectal carcinoma, including ABL1. ABL1 was significantly increased in GC patients with depression compared with that without depression (Table I, and unpublished data). Similarly, in colorectal carcinoma, we also concluded that ABL1 was significantly increased (Fig. 3) (13). Vitally, with whole-genome cRNA microarrays, Yi et al screened 30 differently expressed genes 
Table I. Different expressions of genes involved in DNA-damage signaling pathways in GC patients without and with depression.

\begin{tabular}{|c|c|c|c|c|}
\hline \multirow[b]{2}{*}{ Symbol } & \multirow[b]{2}{*}{ Gene name } & \multicolumn{2}{|c|}{$2^{-\Delta \Delta C t}$} & \multirow{2}{*}{$\frac{\text { Relative expression }}{\text { Group A/group B }}$} \\
\hline & & Group A & Group B & \\
\hline ABL1 & ABL/JTK7 & $4.50 \mathrm{E}-04$ & $7.20 \mathrm{E}-05$ & 6.32 \\
\hline APEX1 & APE/APE1 & 4.10E-01 & $1.50 \mathrm{E}-01$ & 2.69 \\
\hline ATM & AT1/ATA & $9.00 \mathrm{E}-03$ & $1.20 \mathrm{E}-02$ & -1.29 \\
\hline ATR & FRP1/MEC1 & $6.30 \mathrm{E}-03$ & $1.20 \mathrm{E}-02$ & -1.95 \\
\hline ATRX & ATR2/MRXS3 & $1.50 \mathrm{E}-02$ & $2.00 \mathrm{E}-02$ & -1.3 \\
\hline BRCA1 & BRCAI/BRCC1 & $2.00 \mathrm{E}-03$ & $1.50 \mathrm{E}-03$ & 1.34 \\
\hline BTG2 & PC3/TIS21 & $9.20 \mathrm{E}-03$ & $4.20 \mathrm{E}-03$ & 2.16 \\
\hline $\mathrm{CCNH}$ & $\mathrm{CAK} / \mathrm{p} 34$ & $2.10 \mathrm{E}-04$ & $5.00 \mathrm{E}-04$ & -2.35 \\
\hline CDK7 & CAK1/CDKN7 & $1.20 \mathrm{E}-02$ & $7.80 \mathrm{E}-03$ & 1.51 \\
\hline CHEK1 & CHK1 & $3.80 \mathrm{E}-02$ & $2.40 \mathrm{E}-02$ & 1.6 \\
\hline CHEK2 & CDS1/CHK2 & $1.50 \mathrm{E}-02$ & $8.10 \mathrm{E}-03$ & 1.8 \\
\hline CIB1 & CALMYRIN/CIB & $3.00 \mathrm{E}-01$ & $4.20 \mathrm{E}-01$ & -1.42 \\
\hline CIDEA & CIDE-A & $1.10 \mathrm{E}-04$ & $4.90 \mathrm{E}-05$ & 2.31 \\
\hline CRY1 & PHLL1 & $3.70 \mathrm{E}-02$ & $2.10 \mathrm{E}-02$ & 1.77 \\
\hline DDB1 & DDBA/UV-DDB1 & $1.20 \mathrm{E}-01$ & $8.00 \mathrm{E}-02$ & 1.54 \\
\hline DDIT3 & CEBPZ/CHOP & $3.20 \mathrm{E}-02$ & $1.10 \mathrm{E}-01$ & -3.34 \\
\hline DMC1 & DMC1H/HsLim15 & $3.70 \mathrm{E}-04$ & $8.10 \mathrm{E}-04$ & -2.17 \\
\hline ERCC1 & UV20 & $5.60 \mathrm{E}-02$ & $6.30 \mathrm{E}-02$ & -1.13 \\
\hline ERCC2 & EM9/XPD & $1.90 \mathrm{E}-02$ & $3.10 \mathrm{E}-02$ & -1.62 \\
\hline EXO1 & HEX1/hExoI & $2.10 \mathrm{E}-02$ & $1.30 \mathrm{E}-02$ & 1.68 \\
\hline FANCG & FAG/XRCC9 & $2.40 \mathrm{E}-02$ & $2.00 \mathrm{E}-02$ & 1.23 \\
\hline FEN1 & FEN-1/MF1 & $3.60 \mathrm{E}-02$ & $1.00 \mathrm{E}-02$ & 3.58 \\
\hline XRCC6 & СТC75/CTCBF & $2.40 \mathrm{E}-01$ & $2.30 \mathrm{E}-01$ & 1.06 \\
\hline GADD45A & DDIT1/GADD45 & $6.80 \mathrm{E}-03$ & $1.30 \mathrm{E}-02$ & -1.91 \\
\hline GADD45G & CR6/DDIT2 & $4.60 \mathrm{E}-03$ & $2.20 \mathrm{E}-02$ & -4.82 \\
\hline GML & LY6DL & $3.10 \mathrm{E}-05$ & $4.90 \mathrm{E}-05$ & -1.56 \\
\hline GTF2H1 & BTF2/TFIIH & $3.50 \mathrm{E}-02$ & $2.00 \mathrm{E}-02$ & 1.82 \\
\hline GTF2H2 & BTF2/BTF2P44 & $8.50 \mathrm{E}-03$ & $2.00 \mathrm{E}-02$ & -2.3 \\
\hline GTSE1 & B99 & $3.80 \mathrm{E}-02$ & $7.50 \mathrm{E}-02$ & -1.99 \\
\hline HUS1 & Hus1 & $3.50 \mathrm{E}-02$ & $4.80 \mathrm{E}-02$ & -1.38 \\
\hline IGHMBP2 & CATF1/HCSA & $1.20 \mathrm{E}-02$ & $3.30 \mathrm{E}-02$ & -2.75 \\
\hline IHPK3 & INSP6K3/IP6K3 & $6.10 \mathrm{E}-05$ & $5.70 \mathrm{E}-03$ & -93.05 \\
\hline XRCC6BP1 & KUB3 & $2.50 \mathrm{E}-02$ & $1.10 \mathrm{E}-02$ & 2.25 \\
\hline LIG1 & MGC117397 & $2.30 \mathrm{E}-02$ & $6.20 \mathrm{E}-02$ & -2.69 \\
\hline MAP2K6 & MAPKK6/MEK6 & $1.00 \mathrm{E}-02$ & $3.30 \mathrm{E}-03$ & 3.12 \\
\hline MAPK12 & ERK3/ERK6 & $3.00 \mathrm{E}-03$ & $2.50 \mathrm{E}-03$ & 1.19 \\
\hline MBD4 & MED1 & $6.20 \mathrm{E}-02$ & $9.40 \mathrm{E}-02$ & -1.53 \\
\hline MLH1 & COCA2/FCC2 & $1.80 \mathrm{E}-02$ & $1.10 \mathrm{E}-02$ & 1.74 \\
\hline MLH3 & HNPCC/HNPCC7 & $3.60 \mathrm{E}-02$ & $4.70 \mathrm{E}-02$ & -1.31 \\
\hline MNAT1 & MAT1/RNF66 & $1.10 \mathrm{E}-02$ & $1.70 \mathrm{E}-02$ & -1.57 \\
\hline MPG & AAG/APNG & $1.50 \mathrm{E}-01$ & $1.50 \mathrm{E}-01$ & -1 \\
\hline MRE11A & ATLD/HNGS1 & $2.50 \mathrm{E}-02$ & $4.50 \mathrm{E}-02$ & -1.78 \\
\hline MSH2 & COCA1/FCC1 & $2.10 \mathrm{E}-02$ & $1.40 \mathrm{E}-02$ & 1.49 \\
\hline MSH3 & MSH3 & 8.60E-03 & $1.70 \mathrm{E}-02$ & -2.03 \\
\hline MUTYH & MYH/MYH $\beta$ & 7.70E-02 & $1.90 \mathrm{E}-01$ & -2.46 \\
\hline N4BP2 & B3BP & $2.40 \mathrm{E}-03$ & $5.30 \mathrm{E}-03$ & -2.17 \\
\hline NBN & AT-V1/AT-V2 & $6.70 \mathrm{E}-02$ & $2.00 \mathrm{E}-02$ & 3.43 \\
\hline NTHL1 & NTH1/OCTS3 & $5.10 \mathrm{E}-02$ & $1.30 \mathrm{E}-01$ & -2.48 \\
\hline OGG1 & HMMH/HOGG1 & $3.40 \mathrm{E}-02$ & $3.00 \mathrm{E}-02$ & 1.15 \\
\hline PCBP4 & LIP4/MCG10 & $2.60 \mathrm{E}-04$ & $2.30 \mathrm{E}-03$ & -8.69 \\
\hline PCNA & MGC8367 & $6.10 \mathrm{E}-01$ & $1.30 \mathrm{E}-01$ & 4.82 \\
\hline
\end{tabular}


Table I. Continued.

\begin{tabular}{|c|c|c|c|c|}
\hline \multirow[b]{2}{*}{ Symbol } & \multirow[b]{2}{*}{ Gene name } & \multicolumn{2}{|c|}{$2^{-\Delta \Delta C t}$} & \multirow{2}{*}{$\frac{\text { Relative expression }}{\text { Group A/group B }}$} \\
\hline & & Group A & Group B & \\
\hline PDCD8 & AIF & $6.70 \mathrm{E}-02$ & $1.10 \mathrm{E}-01$ & -1.64 \\
\hline PMS1 & DKFZp781M0253/HNPCC3 & $1.60 \mathrm{E}-02$ & $2.10 \mathrm{E}-02$ & -1.27 \\
\hline PMS2 & HNPCC4/PMS2CL & $2.50 \mathrm{E}-02$ & $4.50 \mathrm{E}-02$ & -1.78 \\
\hline PMS2L3 & PMS2L9/PMS5 & $1.30 \mathrm{E}-02$ & $4.40 \mathrm{E}-02$ & -3.39 \\
\hline PNKP & PNK & $3.00 \mathrm{E}-02$ & $6.30 \mathrm{E}-02$ & -2.13 \\
\hline PPP1R15A & GADD34 & $4.70 \mathrm{E}-03$ & $5.50 \mathrm{E}-03$ & -1.17 \\
\hline PRKDC & DNAPK/DNPK1 & $2.70 \mathrm{E}-02$ & $3.60 \mathrm{E}-02$ & -1.31 \\
\hline RAD1 & HRAD1/REC1 & $8.60 \mathrm{E}-03$ & $1.10 \mathrm{E}-02$ & -1.26 \\
\hline RAD17 & CCYC/HRAD17 & $1.90 \mathrm{E}-02$ & $3.90 \mathrm{E}-02$ & -2.07 \\
\hline RAD18 & RNF73 & $7.90 \mathrm{E}-03$ & $1.20 \mathrm{E}-02$ & -1.48 \\
\hline RAD21 & HR21/HRAD21 & $5.10 \mathrm{E}-01$ & $9.50 \mathrm{E}-02$ & 5.31 \\
\hline RAD50 & RAD50-2/hRad50 & $1.20 \mathrm{E}-02$ & $1.00 \mathrm{E}-02$ & 1.14 \\
\hline RAD51 & BRCC5/HRAD51 & $7.70 \mathrm{E}-03$ & $1.90 \mathrm{E}-03$ & 4.03 \\
\hline RAD51L1 & R51H2/RAD51B & $1.90 \mathrm{E}-03$ & $2.90 \mathrm{E}-03$ & -1.53 \\
\hline RAD9A & RAD9 & $9.40 \mathrm{E}-06$ & 4.90E-05 & -5.21 \\
\hline RBBP8 & CTIP/RIM & $7.80 \mathrm{E}-02$ & $5.70 \mathrm{E}-02$ & 1.38 \\
\hline REV1L & REV1 & $2.00 \mathrm{E}-02$ & $4.40 \mathrm{E}-02$ & -2.2 \\
\hline RPA1 & HSSB/REPA1 & $4.00 \mathrm{E}-02$ & $3.90 \mathrm{E}-02$ & 1.02 \\
\hline SEMA4A & SEMAB/SEMB & $2.10 \mathrm{E}-03$ & $1.50 \mathrm{E}-03$ & 1.37 \\
\hline SESN1 & PA26/SEST1 & $7.40 \mathrm{E}-02$ & $1.00 \mathrm{E}-02$ & 7.36 \\
\hline SMC1L1 & DKFZp686L19178/DXS423E & $6.00 \mathrm{E}-02$ & $8.30 \mathrm{E}-02$ & -1.38 \\
\hline SUMO1 & GMP1/PIC1 & $2.70 \mathrm{E}-01$ & 2.60E-01 & 1.05 \\
\hline TP53 & LFS1/TRP53 & $2.80 \mathrm{E}-02$ & $1.20 \mathrm{E}-02$ & 2.39 \\
\hline TP73 & P73 & $1.30 \mathrm{E}-03$ & $3.50 \mathrm{E}-03$ & -2.81 \\
\hline TREX1 & ATRIP/DKFZp434J0310 & 4.70E-03 & $8.90 \mathrm{E}-03$ & -1.91 \\
\hline UNG & DGU/DKFZp781L1143 & $3.20 \mathrm{E}-02$ & $1.00 \mathrm{E}-02$ & 3.12 \\
\hline XPA & XP1/XPAC & $9.50 \mathrm{E}-02$ & $4.50 \mathrm{E}-02$ & 2.1 \\
\hline XPC & XP3/XPCC & $1.10 \mathrm{E}-02$ & $3.00 \mathrm{E}-02$ & -2.68 \\
\hline XRCC1 & $\mathrm{RCC}$ & $2.80 \mathrm{E}-02$ & $5.90 \mathrm{E}-02$ & -2.07 \\
\hline $\mathrm{XRCC} 2$ & DKFZp781P0919 & $7.30 \mathrm{E}-03$ & $3.60 \mathrm{E}-03$ & 2.04 \\
\hline XRCC3 & XRCC3 & $1.70 \mathrm{E}-02$ & $1.00 \mathrm{E}-02$ & 1.62 \\
\hline ZAK & AZK/MLK7 & $3.60 \mathrm{E}-02$ & $2.40 \mathrm{E}-02$ & 1.52 \\
\hline
\end{tabular}

Group A represents GC patients with depression; group B represents GC patients without depression. GC, gastric cancer; MAPK, mitogen-activated protein kinase; ERK, extracellular signal-regulated kinase.

in patients with MDD, including ABL1 (12). In response to OS, ABL1 is the first to induce an adaptive pathway to protect the cell from ROS injury. ABL1 can upregulate nuclear respiratory factor 2 (NRF2), and NRF2 leads to high levels of antioxidant response elements (AREs), including $\mathrm{NAD}(\mathrm{P}) \mathrm{H}$ :quinone oxidoreductase 1 (NQO1) and aldo-keto reductase $1 \mathrm{C} 1$ (AKR1C1), which antagonize the DNA damage and the generation of ROS $(66,67)$. Nevertheless, the function of NRF2 can be blocked by silent mating-type information regulation 2 homologue 1 (SIRT1), which is a gene that is related to MDD and influences the poor prognosis of GC (68-70). Thus, in GC patients with depression, the dysfunction of the protection system induced by SIRT1 may explain part of the mechanism responsible for the poor prognosis.
Secondly, GC cells exhibit features of the enduring activation of the Kirsten rat sarcoma viral oncogene homolog (K-ras)/extracellular signal-regulated kinase (ERK) signaling pathway (71). The ERK signaling pathway can directly induce the proliferation of cancer cell (72). Additionally, ERK also mediates the expression of miR-21, and increased in miR-21 decrease programmed cell death 4 (PDCD4) levels, which subsequently leads to anti-apoptosis and transformation effect on GC cells $(73,74)$. Additionally, PTEN is also a target of miR-21, and decreased levels of PTEN account for the proliferation of GC cells (75). Indeed, studies have revealed that ABL1 can directly interact with RAS and activate the RAS/ERK signaling pathway to promote carcinogenesis of GC (76). Hence, ROS-dependent ABL1 triggers the RAS/ERK 


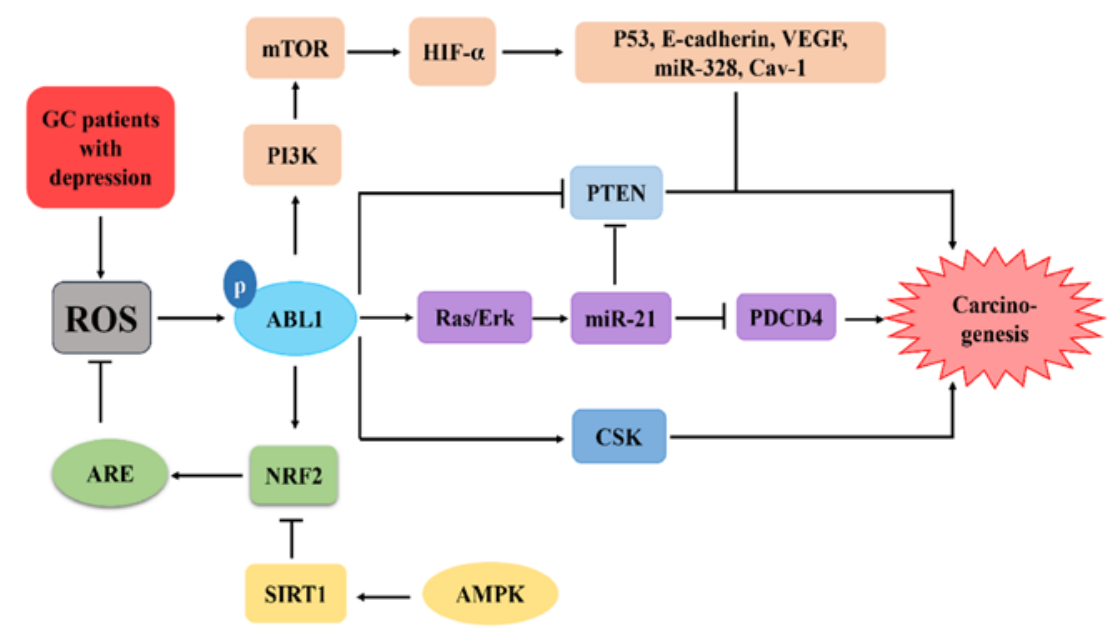

Figure 4. The ABL1-related signaling pathway in cancer development in GC patients with depression. High levels of ROS in GC patients with depression lead to the activation of ABL1, and ABL1 then induces NRF2 to protect cell from ROS injury. ABL1 results in tumorigenesis in GC by phosphorylating its substrates PI3K, Ras, and CSK and the associated signaling pathways. ABL1, ABL proto-oncogene 1; GC, gastric cancer; ROS, reactive oxygen species; NRF2, nuclear factor (erythroid-derived 2)-like 2; PI3K, phosphatidylinositol 3-kinase; CSK, c-Src tyrosine kinase.

signaling pathway to promote the proliferation of GC cells directly or by affecting miR-21.

Third, in GC, hypoxia leads to the generation of ROS that prevent the degradation of HIF-1 $\alpha$ (51). As a transcription factor, the accumulation of HIF-1 $\alpha$ can modulate the expression of genes that are important in gastric tumorigenesis. For example, HIF-1 $\alpha$ attenuates caveolin-1 (Cav-1) and leads to the epithelial-mesenchymal transition (EMT) in GC by regulating E-cadherin (77). HIF-1 $\alpha$ activates the vascular endothelial growth factor (VEGF) pathway to enhance angiogenesis in GC (78). Crosstalk between HIF-1 $\alpha$ and the tumor suppressor gene $\mathrm{p} 53$ has also been discovered, and the expressions of both of these factors are correlated with ROS $(79,80)$. HIF- $1 \alpha$ also induces miR-328 to inhibit the activity of PTEN, which then releases the suppression of the mTOR signaling pathway to promote GC cell survival (81). Notably, ROS-dependent ABL1 directly communicates with p53 in the GC cell line GTL-16 to promote gastric tumorigenesis (48). Moreover, there is also evidence that ABL1 can enhance the activity of HIF-1 $\alpha$ via the mTOR signaling pathway (14). Therefore, ABL1 participates in parts of the mechanism of gastric carcinogenesis by affecting HIF-1 $\alpha$.

Finally, as discussed above, ABL1 can be activated by RTK, and RTK can be activated and act as a substrate of ABL1. One thoroughly investigated factor in GC is CSK (82). Humar et al found that CSK was activated in mesenchyme-like cancer cells and that CSK activation is a central event that is required for the development of early diffuse GC. More importantly, the activation of CSK is mediated by ABL1 via the activation of the Src homology 2 domain-containing 1 (SHC1) of CSK (15). Phosphatidylinositol 3-kinase (PI3K) is also a substrate of ABL1, and the induction of PI3K can trigger the PI3K/v-akt murine thymoma viral oncogene homolog 1 (AKt)/mTOR signaling pathway, which can result in the development of GC $(1,15)$.

For GC patients, excessive ROS are produced due to low levels of antioxidants and high levels of oxidants (83). Moreover, the occurrence of depression among GC patients enhances the production of ROS via a similar mechanism $(13,84)$. ROS act to directly increase the expression of ABL1 $(9,14,85)$.
Additionally, ROS also trigger tyrosine kinase inhibitor (TKI) to increase the activity of ABL1 $(34,61)$. Importantly, in Hp infection-associated GC, ABL1 functions as a proto-oncogene by phosphorylating CagA to promote tumorigenesis $(47,86)$. Taken together, these findings indicate that ABL1 contributes to the protection of cells from ROS by inducing NRF2 and enhancing the activity of HIF-1 $\alpha$ to catalyze its substrate and corresponding substrates to promote carcinogenesis of GC patients with depression (Fig. 4).

\section{Conclusions}

ABL1 regulates cell proliferation in Hp-induced gastric B-cell lymphomas in mucosa-associated lymphoid tissue (MALT) lymphoma, and blocking the activity of ABL1 with imatinib can inhibit cell proliferation (45). GTL16 is a subclone of MKN45 that is characterized as 'Met-addicted' (87). In GTL16, ABL1 has been proven to be activated by Met, and the activation of ABL1 then mediates the phosphorylation of p53 by p38-MAPKs, which results in the overexpression of MDM2, which in turn promotes cell proliferation. Similarly, the effect of ABL1 in GTL16 can be interfered with by imatinib and shRNA interference (48). As discussed above, GC patients with depression have high levels of ROS, and ABL1 may be directly regulated by ROS-related methylation or miR-203, or the ROS-activated ligands of ABL1 may act to indirectly promote the activation of ABL1. Therefore, treatments with TKIs may be clinically beneficial for GC patients with depression.

\section{Perspective}

Collectively, considering the above clinical results, depression is a world-class problem and is frequent among cancer patients. Depression in GC patients is associated with shorter survival times. Worse, there are no ideal drugs for clinical depression. Therefore, the probing of the underlying molecular changes associated with depression in cancer patients represents a new option. We focus our studies on the role of OS and its product ROS in GC and depression and conclude that ROS serve as 
a crosslink for both; i.e., ROS mediate a mutual promotion process for depression and GC. In this review, we elucidated the molecular mechanism of the poor prognosis of GC patients with depression and found that ABL1, which is a non-receptor tyrosine kinase, may function as a crucial factor in the development of GC and the poor prognoses of GC patients with depression. High ROS levels in GC patients lead to the activation of $\mathrm{ABL} 1$, and $\mathrm{ABL} 1$ then induces NRF2 to protect the cells from ROS injury. ABL1 results in tumorigenesis in GC by phosphorylating its substrates and activating signaling pathways. Considering that inhibitors of ABL1 have been widely used in the treatment of CML, it is possible to assess the value of ABL1 in the treatment of GC patients with depression.

However, because ABL1 is widely expressed in the human body and is required for the maintenance of normal physiological functions, e.g., tissue development and immune function, it is difficult to avoid the side-effects of ABL1 inhibitors that are related to these physiological functions. Furthermore, the activity of ABL1 is tissue-specific and context-dependent; thus, future explorations of ABL1 should primarily concentrate on research into the biological processes in which ABL1 functions rather than employing old gene-centric styles. Nevertheless, probing the mediation of the ABL1-dependent phosphorylation of GC should elucidate some of the reasons for GC-related cell death. Given the accumulated evidence, the FDA-approved status of TKIs, and the experience of patients with other cancers, including CML, AML, lung and breast cancer, following exposure to these drugs, ABL represents a prospective target for future treatments for GC patients with depression.

\section{Acknowledgements}

This project was supported by the Natural Science Foundation of Shaanxi Province (no.99SM50), the National Natural Science Foundation of China (nos. 81171288 and 81673033) for the research of OS and depression, and the Fundamental Research Funds for the Central Universities (no. 0601-08143036).

\section{References}

1. Riquelme I, Saavedra K, Espinoza JA, Weber H, García P, Nervi B, Garrido M, Corvalán AH, Roa JC and Bizama C: Molecular classification of gastric cancer: Towards a pathway-driven targeted therapy. Oncotarget 6: 24750-24779, 2015.

2. Hong JS and Tian J: Prevalence of anxiety and depression and their risk factors in Chinese cancer patients. Support Care Cancer 22: 453-459, 2014.

3. Delgado-Guay M,Ferrer J, Rieber AG, Rhondali W, Tayjasanant S, Ochoa J, Cantu H, Chisholm G, Williams J, Frisbee-Hume S, et al: Financial distress and its associations with physical and emotional symptoms and quality of life among advanced cancer patients. Oncologist 20: 1092-1098, 2015.

4. Walker J, Hansen CH, Martin P, Symeonides S, Gourley C, Wall L, Weller D, Murray G and Sharpe M; SMaRT (Symptom Management Research Trials) Oncology-3 Team: Integrated collaborative care for major depression comorbid with a poor prognosis cancer (SMaRT Oncology-3): A multicentre randomised controlled trial in patients with lung cancer. Lancet Oncol 15: 1168-1176, 2014.

5. Andersen BL, DeRubeis RJ, Berman BS, Gruman J, Champion VL, Massie MJ, Holland JC, Partridge AH, Bak K, Somerfield MR, et al; American Society of Clinical Oncology: Screening, assessment, and care of anxiety and depressive symptoms in adults with cancer: An American Society of Clinical Oncology guideline adaptation. J Clin Oncol 32: 1605-1619, 2014
6. Jiménez-Fernández S, Gurpegui $\mathrm{M}$, Díaz-Atienza $\mathrm{F}$, Pérez-Costillas L, Gerstenberg M and Correll CU: Oxidative stress and antioxidant parameters in patients with major depressive disorder compared to healthy controls before and after antidepressant treatment: Results from a meta-analysis. J Clin Psychiatry 76: 1658-1667, 2015.

7. Hermes-Lima M, Moreira DC, Rivera-Ingraham GA, Giraud-Billoud M, Genaro-Mattos TC and Campos EG: Preparation for oxidative stress under hypoxia and metabolic depression: Revisiting the proposal two decades later. Free Radic Biol Med 89: 1122-1143, 2015.

8. Chaturvedi R, de Sablet T, Asim M, Piazuelo MB, Barry DP, Verriere TG, Sierra JC, Hardbower DM, Delgado AG, Schneider BG, et al: Increased Helicobacter pylori-associated gastric cancer risk in the Andean region of Colombia is mediated by spermine oxidase. Oncogene 34: 3429-3440, 2015.

9. Warsch W, Grundschober E, Berger A, Gille L, Cerny-Reiterer S, Tigan AS, Hoelbl-Kovacic A, Valent P, Moriggl R and Sexl V: STAT5 triggers BCR-ABL1 mutation by mediating ROS production in chronic myeloid leukaemia. Oncotarget 3: $1669-1687,2012$

10. No authors listed:FH-deficient cancers depend on ABL1-mediated metabolic adaptation. Cancer Discov 5: OF9, 2015.

11. Wang JY: The capable ABL: What is its biological function? Mol Cell Biol 34: 1188-1197, 2014.

12. Yi Z, Li Z, Yu S, Yuan C, Hong W, Wang Z, Cui J, Shi T and Fang Y: Blood-based gene expression profiles models for classification of subsyndromal symptomatic depression and major depressive disorder. PLoS One 7: e31283, 2012

13. Wei YC, Zhou FL, He DL, Bai JR, Hui LY, Wang XY and Nan KJ: The level of oxidative stress and the expression of genes involved in DNA-damage signaling pathways in depressive patients with colorectal carcinoma. J Psychosom Res 66: 259-266, 2009.

14. Sourbier C, Ricketts CJ, Matsumoto S, Crooks DR, Liao PJ, Mannes PZ, Yang Y, Wei MH, Srivastava G, Ghosh S, et al: Targeting ABL1-mediated oxidative stress adaptation in fumarate hydratase-deficient cancer. Cancer Cell 26: 840-850, 2014.

15. Kolch W and Pitt A: Functional proteomics to dissect tyrosine kinase signalling pathways in cancer. Nat Rev Cancer 10: 618-629, 2010.

16. Lv B, Song C, Wu L, Zhang Q, Hou D, Chen P, Yu S, Wang Z, Chu Y, Zhang J, et al: Netrin-4 as a biomarker promotes cell proliferation and invasion in gastric cancer. Oncotarget 6: 9794-9806, 2015.

17. Demitrack ES, Gifford GB, Keeley TM, Carulli AJ, VanDussen KL, Thomas D, Giordano TJ, Liu Z, Kopan R and Samuelson LC: Notch signaling regulates gastric antral LGR5 stem cell function. EMBO J 34: 2522-2536, 2015.

18. Tavoli A, Mohagheghi MA, Montazeri A, Roshan R, Tavoli Z and Omidvari S: Anxiety and depression in patients with gastrointestinal cancer: Does knowledge of cancer diagnosis matter? BMC Gastroenterol 7: 28, 2007.

19. Shi M, Liu D, Duan H, Han C, Wei B, Qian L, Chen C, Guo L, Hu M, Yu M, et al: Catecholamine up-regulates MMP-7 expression by activating AP-1 and STAT3 in gastric cancer. Mol Cancer 9: 269, 2010

20. Audier AG: Determination of a constitutional neuroendocrine factor probably influencing tumor development in man: Prophylactic and therapeutic aspects. Cancer Detect Prev 11: 203-208, 1988.

21. Wei YC, Zhou FL, He DL, Bai JR, Ding H, Wang XY and Nan KJ: Oxidative stress in depressive patients with gastric adenocarcinoma. Int J Neuropsychopharmacol 12: 1089-1096, 2009.

22. Nordin K, Berglund G, Glimelius B and Sjödén PO: Predicting anxiety and depression among cancer patients: A clinical model. Eur J Cancer 37: 376-384, 2001.

23. Hayakawa Y, Ariyama H, Stancikova J, Sakitani K, Asfaha S, Renz BW, Dubeykovskaya ZA, Shibata W, Wang H, Westphalen CB, et al: Mistl expressing gastric stem cells maintain the normal and neoplastic gastric epithelium and are supported by a perivascular stem cell niche. Cancer Cell 28: 800-814, 2015.

24. Lim K, Hyun YM, Lambert-Emo K, Capece T, Bae S, Miller R, Topham DJ and Kim M: Neutrophil trails guide influenza-specific $\mathrm{CD} 8^{+} \mathrm{T}$ cells in the airways. Science 349: aaa4352, 2015.

25. Finisguerra V, Di Conza G, Di Matteo M, Serneels J, Costa S, Thompson AA, Wauters E, Walmsley S, Prenen H, Granot Z, et al: MET is required for the recruitment of anti-tumoural neutrophils. Nature 522: 349-353, 2015. 
26. Harker JA, Lewis GM, Mack L and Zuniga EI: Late interleukin-6 escalates T follicular helper cell responses and controls a chronic viral infection. Science 334: 825-829, 2011.

27. Hodes GE, Kana V, Menard C, Merad M and Russo SJ: Neuroimmune mechanisms of depression. Nat Neurosci 18: 1386-1393, 2015.

28. Shi Q, Smith TG, Michonski JD, Stein KD, Kaw C and Cleeland CS: Symptom burden in cancer survivors 1 year after diagnosis: A report from the American Cancer Society's Studies of Cancer Survivors. Cancer 117: 2779-2790, 2011

29. Soubeyran P, Fonck M, Blanc-Bisson C, Blanc JF, Ceccaldi J, Mertens C, Imbert Y, Cany L, Vogt L, Dauba J, et al: Predictors of early death risk in older patients treated with first-line chemotherapy for cancer. J Clin Oncol 30: 1829-1834, 2012.

30. Liu Z, Zhang J, Yan J, Wang Y and Li Y: Leucocyte telomere shortening in relation to newly diagnosed type 2 diabetic patients with depression. Oxid Med Cell Longev 2014: 673959, 2014.

31. Rybka J, Kedziora-Kornatowska K, Banaś-Leżańska P, Majsterek I, Carvalho LA, Cattaneo A, Anacker C and Kędziora J: Interplay between the pro-oxidant and antioxidant systems and proinflammatory cytokine levels, in relation to iron metabolism and the erythron in depression. Free Radic Biol Med 63: 187-194, 2013.

32. Yang SL, Yu PL and Chung KR: The glutathione peroxidase-mediated reactive oxygen species resistance, fungicide sensitivity and cell wall construction in the citrus fungal pathogen Alternaria alternata. Environ Microbiol 18: 923-935, 2016.

33. Bhattacharyya A, Chattopadhyay R, Mitra S and Crowe SE: Oxidative stress: An essential factor in the pathogenesis of gastrointestinal mucosal diseases. Physiol Rev 94: 329-354, 2014.

34. Chan EC, Jiang F, Peshavariya HM and Dusting GJ: Regulation of cell proliferation by NADPH oxidase-mediated signaling: Potential roles in tissue repair, regenerative medicine and tissue engineering. Pharmacol Ther 122: 97-108, 2009.

35. Wang $\mathrm{H}, \mathrm{Ma} \mathrm{L}, \mathrm{Li} \mathrm{Y}$ and $\mathrm{Cho} \mathrm{CH}$ : Exposure to cigarette smoke increases apoptosis in the rat gastric mucosa through a reactive oxygen species-mediated and p53-independent pathway. Free Radic Biol Med 28: 1125-1131, 2000.

36. Seo JS, Park JY, Choi J, Kim TK, Shin JH, Lee JK and Han PL: NADPH oxidase mediates depressive behavior induced by chronic stress in mice. J Neurosci 32: 9690-9699, 2012

37. Maes M, Galecki P, Chang YS and Berk M: A review on the oxidative and nitrosative stress (O\&NS) pathways in major depression and their possible contribution to the (neuro)degenerative processes in that illness. Prog Neuropsychopharmacol Biol Psychiatry 35: 676-692, 2011

38. Holm F, Hellqvist E, Mason CN, Ali SA, Delos-Santos N, Barrett CL, Chun HJ, Minden MD, Moore RA, Marra MA, et al: Reversion to an embryonic alternative splicing program enhances leukemia stem cell self-renewal. Proc Natl Acad Sci USA 112: 15444-15449, 2015.

39. Colicelli J: ABL tyrosine kinases: Evolution of function, regulation, and specificity. Sci Signal 3: re6, 2010.

40. De Keersmaecker K, Rocnik JL, Bernad R, Lee BH, Leeman D, Gielen O, Verachtert H, Folens C, Munck S, Marynen P, et al: Kinase activation and transformation by NUP214-ABL1 is dependent on the context of the nuclear pore. Mol Cell 31: 134-142, 2008

41. Jabbour E, Kantarjian H, Ravandi F, Thomas D, Huang X, Faderl S, Pemmaraju N, Daver N, Garcia-Manero G, Sasaki K, et al: Combination of hyper-CVAD with ponatinib as first-line therapy for patients with Philadelphia chromosome-positive acute lymphoblastic leukaemia: A single-centre, phase 2 study. Lancet Oncol 16: 1547-1555, 2015.

42. Greuber EK, Smith-Pearson P, Wang J and Pendergast AM: Role of ABL family kinases in cancer: From leukaemia to solid tumours. Nat Rev Cancer 13: 559-571, 2013.

43. Deb S, Wong SQ, Li J, Do H, Weiss J, Byrne D, Chakrabarti A, Bosma T, Fellowes A, Dobrovic A, et al; kConFab Investigators: Mutational profiling of familial male breast cancers reveals similarities with luminal A female breast cancer with rare TP53 mutations. Br J Cancer 111: 2351-2360, 2014.

44. Cunningham JM, Vierkant RA, Sellers TA, Phelan C, Rider DN, Liebow M, Schildkraut J, Berchuck A, Couch FJ, Wang X, et al; Ovarian Cancer Association Consortium: Cell cycle genes and ovarian cancer susceptibility: A tagSNP analysis. Br J Cancer 101: 1461-1468, 2009.

45. Craig VJ, Cogliatti SB, Rehrauer H, Wündisch T and Müller A: Epigenetic silencing of microRNA-203 dysregulates ABL1 expression and drives Helicobacter-associated gastric lymphomagenesis. Cancer Res 71: 3616-3624, 2011.
46. Chiang YT, Yen YW and Lo CL: Reactive oxygen species and glutathione dual redox-responsive micelles for selective cytotoxicity of cancer. Biomaterials 61: 150-161, 2015.

47. Müller A: Multistep activation of the Helicobacter pylori effector CagA. J Clin Invest 122: 1192-1195, 2012.

48. Furlan A, Stagni V, Hussain A, Richelme S, Conti F, Prodosmo A, Destro A, Roncalli M, Barilà D and Maina F: Abl interconnects oncogenic Met and p53 core pathways in cancer cells. Cell Death Differ 18: 1608-1616, 2011.

49. Bueno MJ, Pérez de Castro I, Gómez de Cedrón M, Santos J, Calin GA, Cigudosa JC, Croce CM, Fernández-Piqueras J and Malumbres $\mathrm{M}$ : Genetic and epigenetic silencing of microRNA-203 enhances ABL1 and BCR-ABL1 oncogene expression. Cancer Cell 13: 496-506, 2008

50. Faber J, Gregory RI and Armstrong SA: Linking miRNA regulation to BCR-ABL expression: The next dimension. Cancer Cell 13: 467-469, 2008.

51. Park JH, Kim TY, Jong HS, Kim TY, Chun YS, Park JW, Lee CT, Jung HC, Kim NK and Bang YJ: Gastric epithelial reactive oxygen species prevent normoxic degradation of hypoxia-inducible factor-1alpha in gastric cancer cells. Clin Cancer Res 9: 433-440, 2003.

52. Watson CJ, Collier P, Tea I, Neary R, Watson JA, Robinson C, Phelan D, Ledwidge MT, McDonald KM, McCann A, et al: Hypoxia-induced epigenetic modifications are associated with cardiac tissue fibrosis and the development of a myofibroblast-like phenotype. Hum Mol Genet 23: 2176-2188, 2014.

53. Frau M, Feo F and Pascale RM: Pleiotropic effects of methionine adenosyltransferases deregulation as determinants of liver cancer progression and prognosis. J Hepatol 59: 830-841, 2013.

54. Asimakopoulos FA, Shteper PJ, Krichevsky S, Fibach E, Polliack A, Rachmilewitz E, Ben-Neriah Y and Ben-Yehuda D: ABL1 methylation is a distinct molecular event associated with clonal evolution of chronic myeloid leukemia. Blood 94: 2452-2460, 1999.

55. Sun B, Jiang G, Zaydan MA, La Russa VF, Safah H and Ehrlich M: ABL1 promoter methylation can exist independently of BCR-ABL transcription in chronic myeloid leukemia hematopoietic progenitors. Cancer Res 61: 6931-6937, 2001.

56. Hayashi Y, Bardsley MR, Toyomasu Y, Milosavljevic S, Gajdos GB, Choi KM, Reid-Lombardo KM, Kendrick ML, Bingener-Casey J, Tang CM, et al: Platelet-derived growth factor receptor- $\alpha$ regulates proliferation of gastrointestinal stromal tumor cells with mutations in KIT by stabilizing ETV1. Gastroenterology 149: 420-32.e16, 2015.

57. Wu Z, Zhang Z, Ge X, Lin Y, Dai C, Chang J, Liu X, Geng R, Wang $\mathrm{C}, \mathrm{Chen} \mathrm{H}$, et al: Identification of short-form RON as a novel intrinsic resistance mechanism for anti-MET therapy in MET-positive gastric cancer. Oncotarget 6: 40519-40534, 2015.

58. Javle M, Smyth EC and Chau I: Ramucirumab: Successfully targeting angiogenesis in gastric cancer. Clin Cancer Res 20: 5875-5881, 2014

59. Kuboki Y, Yamashita S, Niwa T, Ushijima T, Nagatsuma A, Kuwata T, Yoshino T, Doi T, Ochiai A and Ohtsu A: Comprehensive analyses using next-generation sequencing and immunohistochemistry enable precise treatment in advanced gastric cancer. Ann Oncol 27: 127-133, 2016.

60. Lee J, Lee SE, Kang SY, Do IG, Lee S, Ha SY, Cho J, Kang WK, Jang $\mathrm{J}, \mathrm{Ou} \mathrm{SH}$, et al: Identification of ROS1 rearrangement in gastric adenocarcinoma. Cancer 119: 1627-1635, 2013

61. Höcker M, Rosenberg I, Xavier R, Henihan RJ, Wiedenmann B, Rosewicz S, Podolsky DK and Wang TC: Oxidative stress activates the human histidine decarboxylase promoter in AGS gastric cancer cells. J Biol Chem 273: 23046-23054, 1998.

62. Lorenz S, Deng P, Hantschel O, Superti-Furga G and Kuriyan J: Crystal structure of an SH2-kinase construct of c-Abl and effect of the SH2 domain on kinase activity. Biochem J 468: 283-291, 2015.

63. Dölker N, Górna MW, Sutto L, Torralba AS, Superti-Furga G and Gervasio FL: The SH2 domain regulates c-Abl kinase activation by a cyclin-like mechanism and remodulation of the hinge motion. PLOS Comput Biol 10: e1003863, 2014.

64. Thai M, Ting PY, McLaughlin J, Cheng D, Müschen M, Witte ON and Colicelli J: ABL fusion oncogene transformation and inhibitor sensitivity are mediated by the cellular regulator RIN1. Leukemia 25: 290-300, 2011.

65. Chung KS, Han G, Kim BK, Kim HM, Yang JS, Ahn J, Lee K, Song KB and Won M: A novel antitumor piperazine alkyl compound causes apoptosis by inducing RhoB expression via ROS mediated c Abl/p38 MAPK signaling. Cancer Chemother Pharmacol 72: 1315-1324, 2013. 
66. Chen CC, Chu CB, Liu KJ, Huang CY, Chang JY, Pan WY, Chen HH, Cheng YH, Lee KD, Chen MF, et al: Gene expression profiling for analysis acquired oxaliplatin resistant factors in human gastric carcinoma TSGH-S3 cells: The role of IL-6 signaling and Nrf2/AKR1C axis identification. Biochem Pharmacol 86: 872-887, 2013.

67. Ramos-Gomez M, Kwak MK, Dolan PM, Itoh K, Yamamoto M, Talalay P and Kensler TW: Sensitivity to carcinogenesis is increased and chemoprotective efficacy of enzyme inducers is lost in nrf 2 transcription factor-deficient mice. Proc Natl Acad Sci USA 98: 3410-3415, 2001.

68. Cai N, Bigdeli TB, Kretzschmar W, Li Y, Liang J, Song L, Hu J, Li Q, Jin W, Hu Z, et al; CONVERGE consortium: Sparse whole-genome sequencing identifies two loci for major depressive disorder. Nature 523: 588-591, 2015

69. Nabavi SF, Bilotto S, Russo GL, Orhan IE, Habtemariam S, Daglia M, Devi KP, Loizzo MR, Tundis R and Nabavi SM: Omega-3 polyunsaturated fatty acids and cancer: Lessons learned from clinical trials. Cancer Metastasis Rev 34: 359-380, 2015.

70. Cha EJ, Noh SJ, Kwon KS, Kim CY, Park BH, Park HS, Lee H, Chung MJ, Kang MJ, Lee DG, et al: Expression of DBC1 and SIRT1 is associated with poor prognosis of gastric carcinoma. Clin Cancer Res 15: 4453-4459, 2009

71. Xing R, Li W, Cui J, Zhang J, Kang B, Wang Y, Wang Z, Liu S and Lu Y: Gastrokine 1 induces senescence through $\mathrm{p} 16 / \mathrm{Rb}$ pathway activation in gastric cancer cells. Gut 61: 43-52, 2012

72. Leto SM, Sassi F, Catalano I, Torri V, Migliardi G, Zanella ER, Throsby M, Bertotti A and Trusolino L: Sustained inhibition of HER 3 and EGFR is necessary to induce regression of HER2-amplified gastrointestinal carcinomas. Clin Cancer Res 21: 5519-5531, 2015.

73. Tu H, Sun H, Lin Y, Ding J, Nan K, Li Z, Shen Q and Wei Y: Oxidative stress upregulates PDCD4 expression in patients with gastric cancer via miR-21. Curr Pharm Des 20: 1917-1923, 2014

74. Ling M, Li Y, Xu Y, Pang Y, Shen L, Jiang R, Zhao Y, Yang X, Zhang J, Zhou J, et al: Regulation of miRNA-21 by reactive oxygen species-activated ERK/NF- $\kappa \mathrm{B}$ in arsenite-induced cell transformation. Free Radic Biol Med 52: 1508-1518, 2012.

75. Shi Z, Zhang J, Qian X, Han L, Zhang K, Chen L, Liu J, Ren Y, Yang M, Zhang A, et al: AC1MMYR2, an inhibitor of dicer-mediated biogenesis of Oncomir miR-21, reverses epithelial-mesenchymal transition and suppresses tumor growth and progression. Cancer Res 73: 5519-5531, 2013.

76. Albano F, Zagaria A, Anelli L, Coccaro N, Impera L, Minervini CF, Minervini A, Rossi AR, Tota G, Casieri P, et al: Gene expression profiling of chronic myeloid leukemia with variant $\mathrm{t}(9 ; 22)$ reveals a different signature from cases with classic translocation. Mol Cancer 12: 36, 2013.
77. Kannan A, Krishnan A, Ali M, Subramaniam S, Halagowder D and Sivasithamparam ND: Caveolin-1 promotes gastric cancer progression by up-regulating epithelial to mesenchymal transition by crosstalk of signalling mechanisms under hypoxic condition. Eur J Cancer 50: 204-215, 2014.

78. Rath S, Das L, Kokate SB, Pratheek BM, Chattopadhyay S, Goswami C, Chattopadhyay R, Crowe SE and Bhattacharyya A: Regulation of Noxa-mediated apoptosis in Helicobacter pylori-infected gastric epithelial cells. FASEB J 29: 796-806, 2015.

79. Sumiyoshi Y, Kakeji Y, Egashira A, Mizokami K, Orita H and Maehara Y: Overexpression of hypoxia-inducible factor 1alpha and p53 is a marker for an unfavorable prognosis in gastric cancer. Clin Cancer Res 12: 5112-5117, 2006.

80. Hammond EM and Giaccia AJ: Hypoxia-inducible factor-1 and p53: Friends, acquaintances, or strangers? Clin Cancer Res 12: 5007-5009, 2006.

81. Seok JK, Lee SH, Kim MJ and Lee YM: MicroRNA-382 induced by HIF-1 $\alpha$ is an angiogenic miR targeting the tumor suppressor phosphatase and tensin homolog. Nucleic Acids Res 42: 8062-8072, 2014

82. Humar B, Fukuzawa R, Blair V, Dunbier A, More H, Charlton A, Yang HK, Kim WH, Reeve AE, Martin I, et al: Destabilized adhesion in the gastric proliferative zone and c-Src kinase activation mark the development of early diffuse gastric cancer. Cancer Res 67: 2480-2489, 2007.

83. Bauer G, Bereswill S, Aichele P and Glocker E: Helicobacter pylori protects oncogenically transformed cells from reactive oxygen species-mediated intercellular induction of apoptosis. Carcinogenesis 35: 1582-1591, 2014.

84. Mendes-da-SilvaRF,Lopes-de-Morais AA,Bandim-da-SilvaME, Cavalcanti GA, Rodrigues AR, Andrade-da-Costa BL and Guedes RC: Prooxidant versus antioxidant brain action of ascorbic acid in well-nourished and malnourished rats as a function of dose: A cortical spreading depression and malondialdehyde analysis. Neuropharmacology 86: 155-160, 2014.

85. Bolton-Gillespie E, Schemionek M, Klein HU, Flis S, Hoser G, Lange T, Nieborowska-Skorska M, Maier J, Kerstiens L, Koptyra M, et al: Genomic instability may originate from imatinib-refractory chronic myeloid leukemia stem cells. Blood 121: 4175-4183, 2013.

86. Wei J, O'Brien D, Vilgelm A, Piazuelo MB, Correa P, Washington MK, El-Rifai W, Peek RM and Zaika A: Interaction of Helicobacter pylori with gastric epithelial cells is mediated by the $\mathrm{p} 53$ protein family. Gastroenterology 134: 1412-1423, 2008.

87. Bertotti A, Bracco C, Girolami F, Torti D, Gastaldi S, Galimi F, Medico E, Elvin P, Comoglio PM and Trusolino L: Inhibition of Src impairs the growth of met-addicted gastric tumors. Clin Cancer Res 16: 3933-3943, 2010. 